\title{
Growth and Development of PuRple Nutsedge Based on Days or TherMal UNITS ${ }^{1}$
}

\author{
Crescimento e Desenvolvimento da Tiririca com Base em Dias ou Unidades Térmicas
}

\author{
LIMA, R.S.O. ${ }^{2}$, MACHADO, E.C.R. ${ }^{2}$, SILVA, A.P.P. ${ }^{2}$, MARQUES, B.S. ${ }^{2}$, GONÇALVES, M.F. ${ }^{2}$, and \\ CARVALHO, S.J.P. ${ }^{3}$
}

\begin{abstract}
This work was carried out with the objective of elaborating mathematical models to predict growth and development of purple nutsedge (Cyperus rotundus) based on days or accumulated thermal units (growing degree days). Thus, two independent trials were developed, the first with a decreasing photoperiod (March to July) and the second with an increasing photoperiod (August to November). In each trial, ten assessments of plant growth and development were performed, quantifying total dry matter and the species phenology. After that, phenology was fit to first degree equations, considering individual trials or their grouping. In the same way, the total dry matter was fit to logistic-type models. In all regressions four temporal scales possibilities were assessed for the $x$ axis: accumulated days or growing degree days (GDD) with base temperatures (Tb) of 10,12 and $15{ }^{\circ} \mathrm{C}$. For both photoperiod conditions, growth and development of purple nutsedge were adequately fit to prediction mathematical models based on accumulated thermal units, highlighting $\mathrm{Tb}=12{ }^{\circ} \mathrm{C}$. Considering GDD calculated with $\mathrm{Tb}=12{ }^{\circ} \mathrm{C}$, purple nutsedge phenology may be predicted by $y=0.113 x$, while species growth may be predicted by $y=37.678 /\left(1+(x / 509.353)^{-7.047}\right)$.
\end{abstract}

Keywords: Cyperus rotundus, growing degree days, phenology, base temperature, modeling.

RESUMO - Este trabalho foi desenvolvido com o objetivo de elaborar modelos matemáticos para previsão do crescimento e desenvolvimento da tiririca (Cyperus rotundus) com base em dias ou unidades térmicas acumuladas (graus-dia). Para isso, dois experimentos independentes foram desenvolvidos: o primeiro com fotoperiodo decrescente (março a julho) e o segundo com fotoperiodo crescente (agosto a novembro). Em cada experimento, foram realizadas dez avaliações de crescimento e desenvolvimento das plantas, quantificando-se a massa de matéria seca e a fenologia da espécie. Posteriormente, a fenologia foi ajustada a equações de primeiro grau, considerando-se os experimentos isolados e o agrupamentos destes. Da mesma forma, a massa seca total foi ajustada a modelos do tipo logistico. Em todas as regressões, avaliaram-se quatro possibilidades de escalas temporais para o eixo $x$ : dias ou graus-dia acumulados, com temperatura basal (Tb) de 10, 12 e $15^{\circ} \mathrm{C}$. Em ambas as condições de fotoperiodo, o crescimento e o desenvolvimento da tiririca foram adequadamente ajustados a modelos matemáticos de previsão com base em unidades térmicas acumuladas, com destaque para $\mathrm{Tb}=12^{\circ} \mathrm{C}$. Considerando-se graus-dia acumulados $(x)$ calculados com $\mathrm{Tb}=12^{\circ} \mathrm{C}$, a fenologia da tiririca pode ser prevista por $y=0,113 x$, enquanto o crescimento da espécie pode ser previsto por $y=37,678 /\left(1+(x / 509,353)^{-7,047}\right)$.

Palavras-chave: Cyperus rotundus, graus-dia, fenologia, temperatura basal, modelagem.

1 Recebido para publicação em 7.8.2014 e aprovado em 26.1.2015.

2 Graduados em Engenharia Agronômica pelo IFSULDEMINAS - Câmpus Machado, Machado-MG, Brasil; ${ }^{3}$ Professor Doutor, IFSULDEMINAS - Câmpus Machado, Machado-MG, Brasil <sjpcarvalho@yahoo.com.br>. 


\section{INTRODUCTION}

Weeds are major biotic components of the agroecosystem that are capable of negatively interfering in crops. The negative effects are expressed on the quantity and quality of the agricultural production, a result of the competition for the environmental growth resources, allelopathy or agents that host pests and diseases, allowing their multiplication. In Brazil, it is believed that the weed interference on agricultural crops is responsible, on average, for yield reductions around 20 to $30 \%$ (Lorenzi, 2006).

There are several weed species present in agricultural areas, among which may be mentioned those classified in the Cyperaceae family. This botanical family consists of approximately 3,000 species, of which about 300 are classified as weeds, and around 42\% of these belong to the genus Cyperus (Bendixen \& Nandihalli, 1987), and purple nutsedge (Cyperus rotundus) significantly standing out.

The purple nutsedge is a herbaceous perennial plant, between 0.10 and $0.60 \mathrm{~m}$ high. It has a $\mathrm{C} 4$ type photosynthetic cycle, i.e., it is highly efficient in performing photosynthesis in high radiation and temperature scenarios. The development of shoots is discreet, with few leaves and inflorescences, whose seeds have minimum viability. On the other hand, it stands out due to its vegetative propagation, since it produces numerous rhizomes and tubers, which greatly promote its spread on agricultural fields.

It has been considered one of the most important weeds in the crops, being classified by Holm et al. (1977) as one of the ten worst weeds in the world. In Brazil, purple nutsedge can be found in all types of soils, climates and cultures, but is particularly undesirable in the areas of sugarcane (Saccharum spp.), where, besides competing for the resources of the environment, it exudes allelopathic compounds that inhibit budding of the crop (Durigan, 1991; Kissmann, 1997). In this environment, the purple nutsedge stands out as an important weed, even in areas with harvest without previous burning (raw cane) (Foloni et al., 2008). Kuva et al. (2007) have assessed the weeds pestering cane raw agroecosystems and found that, of the 28 fields assessed, purple nutsedge had stood out in 20, being the main weed in 13 of them.

In this sense, it is considered that the analysis of the behavior of the weeds regarding the ecological factors, as well as their effect on the environment, mainly regarding their interference on other plants, contributes to the development of integrated management systems (Lucchesi, 1984; Bianco et al., 1995). Still, the growth characteristics of a certain species provide an important indicator of its competitive ability (Holt \& Orkutt, 1991).

While the great importance of studies assessing the biology of weeds is recognized, few studies have discussed the growth and development of these species, mainly based on growing degree days - GDD (thermal units). The prediction of different phenological aspects of crops, weeds and other pests with simple thermal equations tends to be an excellent tool to provide practical solutions to crops problems (Ghersa \& Holt, 1995). Thus this work was carried out with the objective of elaborating mathematical models to predict growth and development of purple nutsedge (Cyperus rotundus) based on days or thermal units (growing degree days).

\section{MATERIALS AND METHODS}

Two independent experiments were carried out in an experimental nursery at the Instituto Federal de Educação, Ciência e Tecnologia do Sul de Minas Gerais (Federal Institute of Education, Science and Technology of Southern Minas Gerais), Campus Machado, MG, Brazil (21 40' S; 45 55' W; $850 \mathrm{~m}$ of altitude). In each experiment, the growth and development of purple nutsedge (Cyperus rotundus) were assessed. The first experiment was developed between March and July 2013 (decreasing photoperiod), while the second one was developed between August and November of the same year (increasing photoperiod).

Cyperus rotundus tubers were collected in agricultural and non-agricultural areas of the Brazilian municipality of Machado, MG, washed and immediately planted in experimental plots, numbering 13 per plot. The experimental plots comprised plastic pots with a capacity of $4 \mathrm{~L}$, filled with a proportion of a commercial substrate and vermiculite 
(3:1; v:v), appropriately fertilized with $25 \mathrm{~g}$ of fertilizer NPK 04:14:08 (N, $\mathrm{P}_{2} \mathrm{O}_{5}$ e $\left.\mathrm{K}_{2} \mathrm{O}\right)$ and $10 \mathrm{~g}$ of ammonium sulfate. Throughout the trial period, there was no manifestation of nutritional deficiency in the plants. The pots were watered whenever necessary, without water deficit. After the emergence of the seedlings, thinning of the pots was performed so as to obtain a constant final density of only one plant per pot.

In both experiments, the experimental design was of randomized blocks with ten treatments (growth evaluations) and three replications. In the first half of the experiments, due to the small variation of matter, growth assessments were spaced in 14 days. In the second half, the matter assessments were spaced in seven days, with total experimental cycles higher than 100 days. In each of the ten assessments, three plots (replicates) were randomly sampled by the destructive method. The plants were washed with tap water to remove the substrate remaining in the roots, and then all the material was dried at $70{ }^{\circ} \mathrm{C}$ for 72 hours. After drying, the total dry weight was measured (g per plant). On the same dates of the matter assessments, the population phenological estimate was also held, using the scale proposed by Hess et al. (1997). In this case, the growth stage was set when a certain development characteristic was observed for $50 \%+1$ of all remaining plants in the population.

The experiments were independently assessed by applying the $\mathrm{F}$ test for analysis of variance with $1 \%$ probability. The phenological data of purple nutsedge were adjusted to the time counting in days after planting (DAP) or to the accumulated thermal units (growing degree days - GDD) by means of the linear regression model $y=a x$, where $y$ concerns the development of purple nutsedge according to the phenological scale (Hess et al., 1997), $x$ concerns the time scale used and $a$ is the model parameter.

In practice, parameter $a$ of this equation can be understood as the percentage of GDD effectively converted into plant phenology units, allowing an estimation of the speed of development of plants in a given season or sowing date (Machado et al., 2014). When necessary, the comparison of two straight lines was made by overlapping the confidence interval of the analysis for parameter $a$ of the equation. Thus, two straight lines were considered equal in the existence of an overlapping of the confidence intervals (Carvalho \& Christoffoleti, 2007).

For calculating the GDD, the equation by Gilmore Jr. \& Rogers (1958) was used:

$$
G D D=\left(\frac{T \max +T \min }{2}\right)-T b
$$

where: Tmax is the maximum daily temperature; Tmin is the minimum daily temperature; and $T b$ concerns the basal temperature of the purple nutsedge, assessed at 10,12 or $15^{\circ} \mathrm{C}$. The daily maximum and minimum temperatures were obtained by the meteorological station installed on campus Machado and made available by Instituto Nacional de Pesquisas Espaciais - INPE (National Institute for Space Research, a research unit of the Brazilian Ministry of Science and Technology) (Figure 1).

The total dry matter was adjusted to logistic type nonlinear regressions, also based on DAP or GDD. The model proposed by Streibig (1988) was adopted:

$$
y=\frac{a}{\left[1+\left(\frac{x}{b}\right)^{c}\right]}
$$

where: $y$ is the total dry matter (g per plant), $x$ is the temporal scale (DAP or GDD) and $a, b$ and $c$ are estimated parameters of the equation ( $a$ is the existing amplitude between the maximum and minimum point of the variable, $b$ corresponds to the value of the temporal scale necessary for the occurrence of $50 \%$ of the response of the variable and $c$ is the slope of the curve around $b$ ).

\section{RESULTS AND DISCUSSION}

Depending on the events that may occur during plant development, there is a need for the adoption of numerical scales to establish levels for this period. Traditionally, days have 


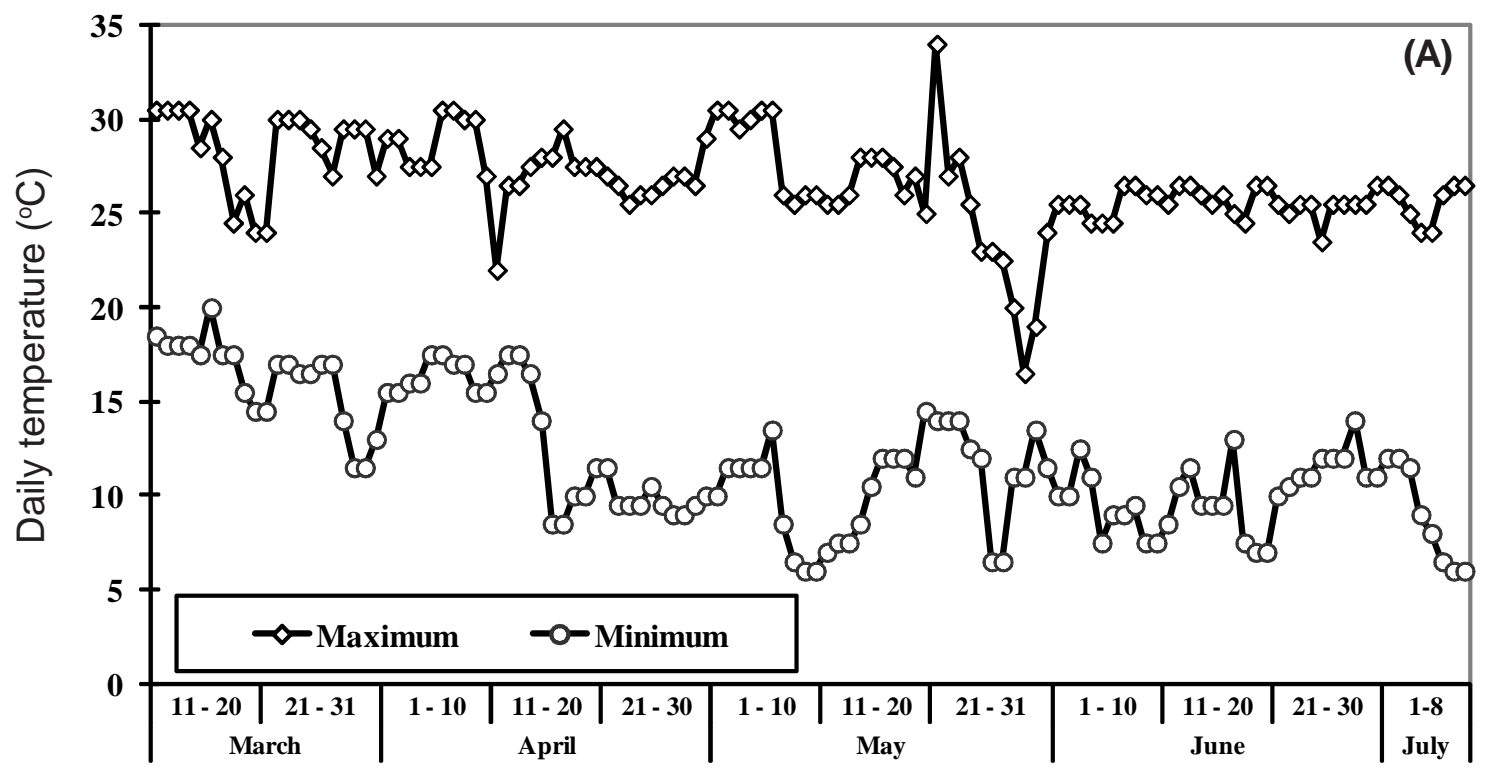

Month/Day (2013)

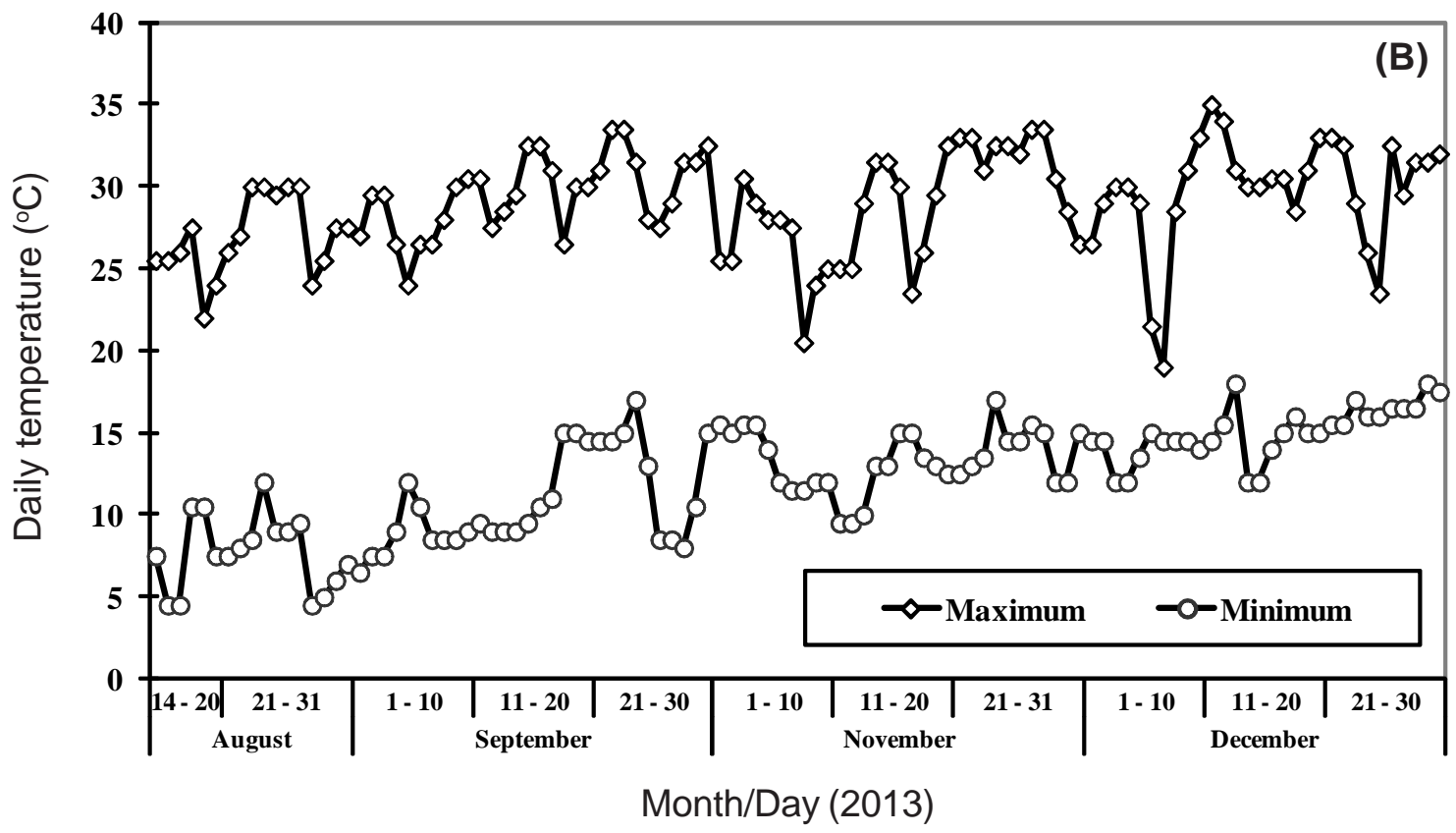

Figure 1 - Daily maximum and minimum temperatures for the period and site of the experiment development. (A) first semester of 2013; (B) second semester of 2013. Machado, MG, 2013.

been used as a cycle timing, but it is a variable that is very much subject to environmental interferences which indirectly are also expressed on the phenology (Silva et al., 2014). Therefore, temperature has been considered the most important climatic element to predict physiological events, if there is no water deficit (Russelle et al., 1984; Gadioli et al., 2000).
The method of growing degree days - GDD is based on the premise that a plant needs a certain amount of energy, represented by the sum of the thermal degrees required to complete a certain phenological phase or even the total cycle. It allows, in addition, a linear relationship between the increase of temperature and the plant development 
(Gadioli et al., 2000). Thus, it becomes possible to use mathematical models and simulation routines that use the concept of GDD (Medeiros et al., 2000).

In the case of the purple nutsedge, independently in each experiment, a proper adjustment of the phenological development to the time scales used was obtained in DAP or GDD by means of the first-degree linear equation, with coefficients of determination always above 90\% (Table 1). For all scales, there was an overlap of confidence intervals of parameter $a$ of the equation between the experiments developed in increasing and decreasing photoperiods, which indicates a similar behavior for the development of purple nutsedge in different seasons (Carvalho \& Christoffoleti, 2007). In this case, a decision was made for performing a joint analysis of the experiments (Table 1) by means of the general cumulative points (Figure 2).

Also in the case of the joint analysis an appropriate mathematical adjustment for all scales used was obtained, with coefficients of determination higher than 85\% (Table 1; Figure 2). Adoption of the base temperature (Tb) of $12{ }^{\circ} \mathrm{C}$ must be highlighted, which resulted in lower mean square of the residue $\left(\mathrm{MS}_{\text {residue }}=67.652\right)$, greater significance of the model to $\mathrm{F}$ test $\left(\mathrm{F}=1184.270^{* *}\right)$ and a higher coefficient of determination $\left(\mathrm{R}^{2}=0.918\right)$ (Table 1).

Base temperature (Tb) is the minimal temperature for growth of a given species, below which growth ceases or is greatly reduced. In literature are considered values of $\mathrm{Tb}=0{ }^{\circ} \mathrm{C}$ for weeds and temperate climate crops such as barley (Hordeum vulgare) and wheat (Triticum aestivum) (Cao \& Moss, 1989; Kirkby, 1995). For sunflower (Helianthus annuus), Granier \& Tardieu (1998) suggested base temperature around $4.8^{\circ} \mathrm{C}$.

For redroot pigweed (Amaranthus retroflexus), species with photosynthetic cycle type $\mathrm{C}_{4}$, Gramig \& Stoltenberg (2007) have recorded $\mathrm{Tb}=8.5$. Base temperatures around $10{ }^{\circ} \mathrm{C}$ were reported for Leonurus sibiricus (Silva et al., 2014), for common beans (Phaseolus vulgaris) (Medeiros et al., 2000), for maize crop (Gadioli et al., 2000) and for bunch grass Panicum virgatum (Sanderson \& Wolf, 1995). Machado et al. (2014) have obtained $\mathrm{Tb}=12{ }^{\circ} \mathrm{C}$ for southern sandbur (Cenchrus echinatus). Also, Villa Nova et al. (1999) have used $\mathrm{Tb}=15{ }^{\circ} \mathrm{C}$ for elephant grass cv. Napier (Pennisetum purpureum), especially a Poaceae family plant of tropical climate.

Thus, considering the phenological development on the proposed scales, data

Table 1 - Adopted scale, residue mean square $\left(\mathrm{MS}_{\text {residue }}\right)$ of the model ${ }^{1 /}$, F test of the model, coefficient of determination $\left(\mathrm{R}^{2}\right)$, parameter $a$ of the equation and confidence interval (CI) at 5\% significance, for adjustment of the phenology of Cyperus rotundus to the days and to growing degree days in all experimental conditions. Machado, MG, 2013

\begin{tabular}{|c|c|c|c|c|c|c|c|}
\hline \multirow{2}{*}{ Photoperiod } & \multirow{2}{*}{ Scale } & \multirow{2}{*}{$\mathrm{MS}_{\text {residue }}$} & \multirow{2}{*}{$\mathrm{F}$} & \multirow{2}{*}{$\mathrm{R}^{2}$} & \multirow{2}{*}{$a$} & \multicolumn{2}{|c|}{ CI (5\%) } \\
\hline & & & & & & Minimum & Maximum \\
\hline \multirow{4}{*}{ Decreasing } & $\mathrm{Tb} 10^{\circ} \mathrm{C}$ & 71.644 & $569.519 * *$ & 0.983 & 0.094* & 0.086 & 0.103 \\
\hline & $\mathrm{Tb} 12{ }^{\circ} \mathrm{C}$ & 58.583 & $698.726 * *$ & 0.986 & $0.118^{*}$ & 0.108 & 0.128 \\
\hline & $\operatorname{Tb} 15^{\circ} \mathrm{C}$ & 38.743 & $1061.630 * *$ & 0.991 & $0.191^{*}$ & 0.178 & 0.204 \\
\hline & Days & 153.734 & $260.070 * *$ & 0.963 & $0.920 *$ & 0.792 & 1.047 \\
\hline \multirow{4}{*}{ Increasing } & $\mathrm{Tb} 10^{\circ} \mathrm{C}$ & 56.707 & 695.737** & 0.986 & 0.086* & 0.079 & 0.093 \\
\hline & $\mathrm{Tb} 12^{\circ} \mathrm{C}$ & 65.312 & $602.748 * *$ & 0.984 & $0.108^{*}$ & 0.098 & 0.117 \\
\hline & $\mathrm{Tb} 15^{\circ} \mathrm{C}$ & 99.389 & $392.660 * *$ & 0.975 & $0.172 *$ & 0.153 & 0.191 \\
\hline & Days & 36.047 & $1100.200 * *$ & 0.991 & 0.859* & 0.801 & 0.917 \\
\hline \multirow{4}{*}{$\begin{array}{l}\text { General } \\
\text { accumulation }\end{array}$} & $\mathrm{Tb} 10^{\circ} \mathrm{C}$ & 68.949 & $1161.600 * *$ & 0.916 & $0.090 *$ & 0.084 & 0.095 \\
\hline & $\mathrm{Tb} 12{ }^{\circ} \mathrm{C}$ & 67.652 & $1184.270^{* *}$ & 0.918 & $0.113^{*}$ & 0.106 & 0.119 \\
\hline & $\mathrm{Tb} 15^{\circ} \mathrm{C}$ & 76.581 & $1043.750 * *$ & 0.907 & $0.181 *$ & 0.169 & 0.192 \\
\hline & Days & 94.753 & $839.544 * *$ & 0.885 & $0.887 *$ & 0.823 & 0.951 \\
\hline
\end{tabular}

${ }^{1 /}$ Phenology = a.(GDD); $\mathrm{Tb}=$ base temperature; * Significant by t test at $5 \%$ probability; ** Significant at $1 \%$. 

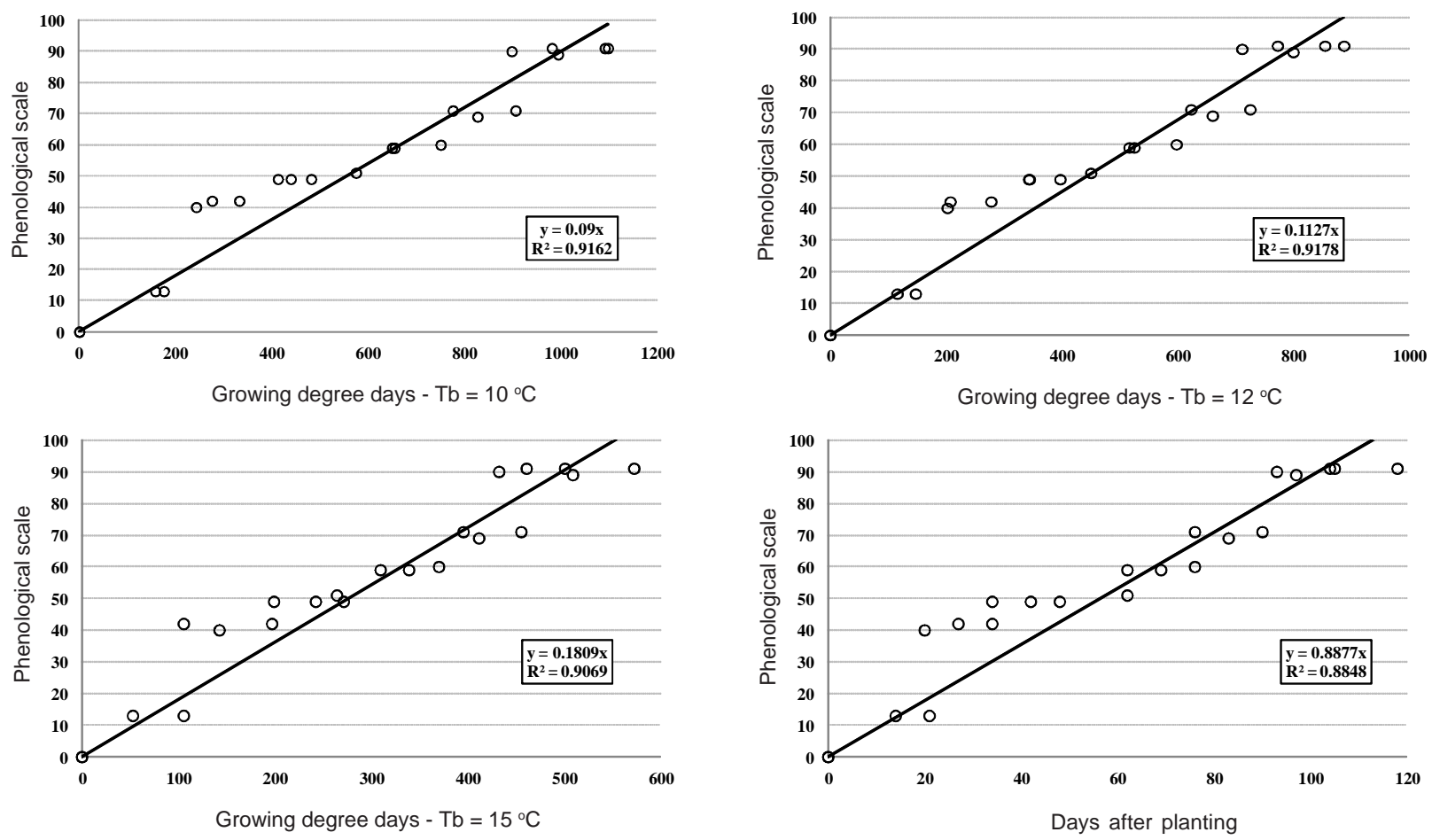

Figure 2 - Adjustment of the purple nutsedge (Cyperus rotundus) phenological development, considering days and growing degree days, calculated with base temperatures (Tb) of 10, 12 and $15^{\circ} \mathrm{C}$. Machado, MG, 2013.

consistency (Table 1), size of the purple nutsedge and the fact that it is a Cyperaceae family species with a $\mathrm{C}_{4}$ type photosynthetic cycle and rating as a perennial weed, assigning $\mathrm{Tb}=12{ }^{\circ} \mathrm{C}$ is suggested as appropriate for future studies.

In a condition of decreasing photoperiod, the beginning of the vegetative propagation (stage 40 - Hess et al. (1997)) it was recorded at 20 DAP, by means of the formation of rhizomes with an accumulation of 200 GDD for $\mathrm{Tb}=12{ }^{\circ} \mathrm{C}$. At the end of the cycle, an average of five tubers formed per plant was observed. For the increasing photoperiod, beginning of vegetative propagation at 27 DAP was recorded, with an accumulation of 150 GDD for $\mathrm{Tb}=12^{\circ} \mathrm{C}$. At the end of the cycle, an average of 3.5 tubers formed per plant was recorded.

The use of growth analysis is one of the easiest and more accurate ways to infer the contribution of different physiological processes for plant growth, enabling the knowledge of plant biomass production kinetics, its distribution and efficiency during ontogeny (Benincasa, 2004). Accordingly, the total dry matter production is recognized as a basic process of plant growth (Radosevich et al., 1997).

In the experiments, in an independent analysis, the total dry matter data were properly fitting to the model, with coefficients of determination above 95\% (Table 2). Slow initial growth was identified for the species, with subsequent exponential accumulation of dry matter after $300 \mathrm{GDD}\left(\mathrm{Tb}=12{ }^{\circ} \mathrm{C}\right)$ and maximum values exceeding $40 \mathrm{~g}$ per plant (Figure 3). All equations based on GDD have set the dry matter accumulation of purple nutsedge with proximity between the slopes of the two experimental conditions, and $\mathrm{Tb}=12{ }^{\circ} \mathrm{C}$ again standing out. The wider gap between the slopes was observed for the use of days as a temporal scale (Figure 3).

Due to the close proximity of the adjustments between different photoperiod conditions, implementing a joint analysis of the experiments based on all the different temporal scales was chosen (Table 2; Figure 4). Also in this case, the best overall adjustment was obtained for $\mathrm{Tb}=12{ }^{\circ} \mathrm{C}$, highlighting the lowest mean square of the residue $\left(\mathrm{MS}_{\text {residue }}=11.498\right)$, the greatest significance 
Growth and development of purple nutsedge based on days ...

Table 2 - Adopted scale, coefficient of determination $\left(\mathrm{R}^{2}\right)$ of the model $\mathrm{l}^{1 /}$ and parameters $a, b$ and $c$ of the logistic equation used for adjustment of the total dry matter of purple nutsedge (Cyperus rotundus) in all experimental conditions. Machado, MG, 2013

\begin{tabular}{|c|c|c|c|c|c|c|c|c|}
\hline \multirow{2}{*}{ Year } & \multirow{2}{*}{ Photoperiod } & \multirow{2}{*}{ Scale } & \multirow{2}{*}{$\mathrm{MS}_{\text {residue }}$} & \multirow{2}{*}{$\mathrm{F}$} & \multicolumn{3}{|c|}{ Model parameters } & \multirow{2}{*}{$\mathrm{R}^{2}$} \\
\hline & & & & & $a$ & $b$ & C & \\
\hline \multirow{4}{*}{2013} & \multirow{4}{*}{ Decreasing } & $\mathrm{Tb} 10^{\circ} \mathrm{C}$ & 7.945 & $145.170^{* *}$ & 35.969 & 609.768 & -5.919 & 0.973 \\
\hline & & $\mathrm{Tb} 12^{\circ} \mathrm{C}$ & 8.124 & $141.891^{* *}$ & 35.917 & 495.337 & -6.329 & 0.972 \\
\hline & & $\mathrm{Tb} 15^{\circ} \mathrm{C}$ & 8.885 & $129.388 * *$ & 35.765 & 323.387 & -7.864 & 0.970 \\
\hline & & Days & 7.481 & $154.421^{* *}$ & 36.221 & 57.152 & -4.601 & 0.975 \\
\hline \multirow{4}{*}{2013} & \multirow{4}{*}{ Increasing } & $\mathrm{Tb} 10^{\circ} \mathrm{C}$ & 13.927 & $99.921^{* *}$ & 38.983 & 654.753 & -8.189 & 0.961 \\
\hline & & $\mathrm{Tb} 12{ }^{\circ} \mathrm{C}$ & 14.092 & $98.709 * *$ & 39.004 & 517.088 & -7.752 & 0.961 \\
\hline & & $\mathrm{Tb} 15^{\circ} \mathrm{C}$ & 14.528 & $95.623 * *$ & 39.004 & 310.460 & -6.668 & 0.959 \\
\hline & & Days & 13.140 & $106.156^{* *}$ & 38.828 & 68.785 & -10.542 & 0.964 \\
\hline & \multirow{4}{*}{ General } & $\mathrm{Tb} 10^{\circ} \mathrm{C}$ & 12.022 & $200.912^{* *}$ & 37.762 & 639.665 & -7.015 & 0.957 \\
\hline & & $\mathrm{Tb} 12^{\circ} \mathrm{C}$ & 11.498 & $210.485^{* *}$ & 37.678 & 509.353 & -7.047 & 0.959 \\
\hline & & $\mathrm{Tb} 15^{\circ} \mathrm{C}$ & 12.496 & $192.958 * *$ & 37.846 & 318.139 & -6.987 & 0.955 \\
\hline & & Days & 17.488 & $135.307 * *$ & 37.687 & 65.628 & -7.536 & 0.937 \\
\hline
\end{tabular}

$\underline{1} / \mathrm{y}=\mathrm{a} /\left(1+(\mathrm{x} / \mathrm{b})^{\mathrm{c}}\right) ; \mathrm{Tb}=$ base temperature; ** Significant at $1 \%$ probability.
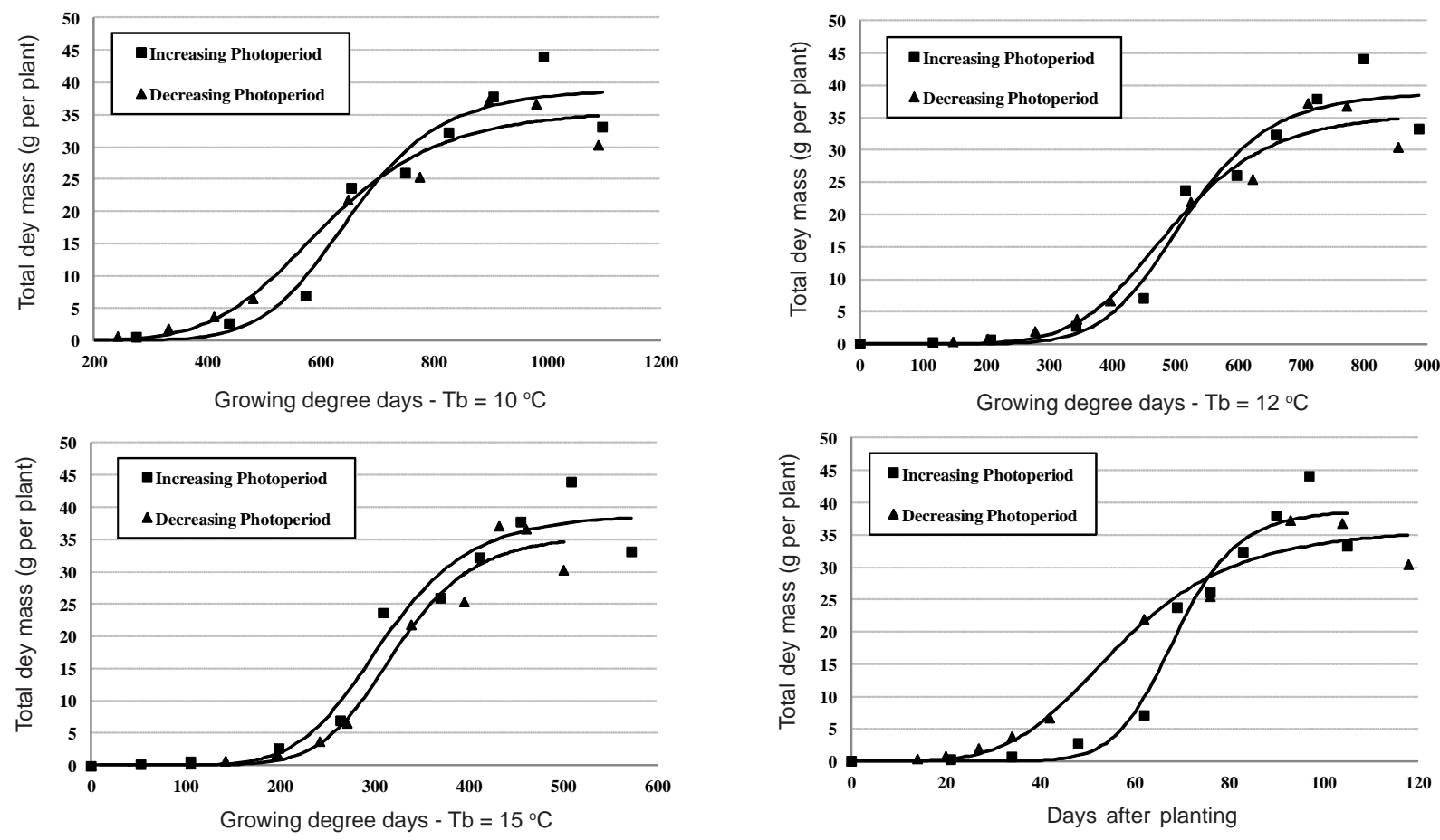

Figure 3 - Accumulation of total dry mass per plants of purple nutsedge (Cyperus rotundus) in two different growth conditions, adjusted to different scales, considering days or growing degree days, calculated with base temperatures (Tb) of $10,12 \mathrm{or} 15^{\circ} \mathrm{C}$. Machado, MG, 2013.

of the model to the $\mathrm{F}$ test $\left(\mathrm{F}=210.485^{* *}\right)$ and the highest coefficient of determination $\left(\mathrm{R}^{2}=0.959\right)$ (Table 2).

Thus, the overall analysis of the results allows one to assume that the growth and development of this weed can be adequately predicted with the use of mathematical models based on accumulated thermal units, especially for the adoption of $\mathrm{Tb}=12{ }^{\circ} \mathrm{C}$. Taking into account the overlap of the straight lines (Table 1), there was no phenological 

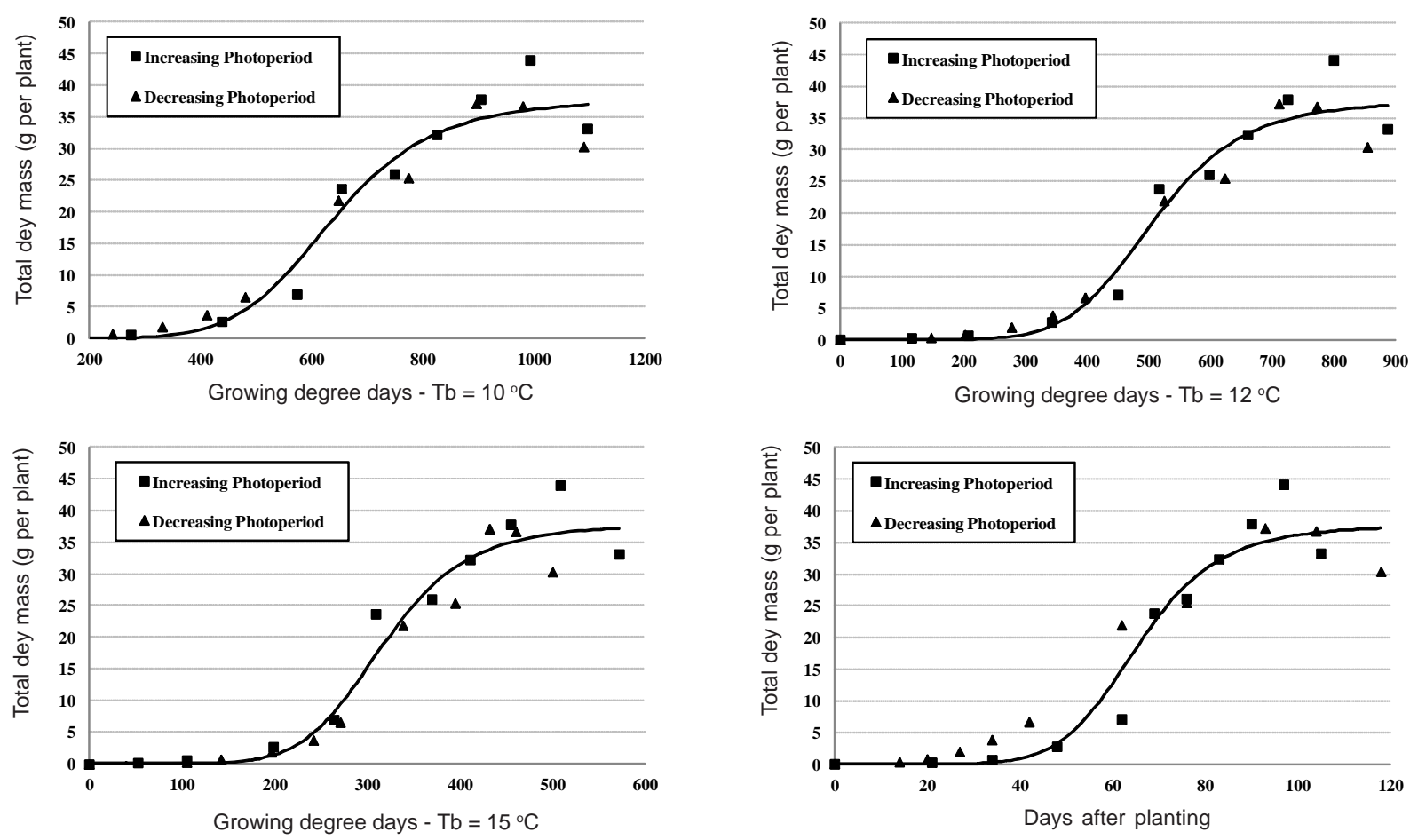

Figure 3 - Accumulation of total dry mass per plants of purple nutsedge (Cyperus rotundus) in two different growth conditions, adjusted to different scales, considering days or growing degree days, calculated with base temperatures (Tb) of 10,12 or $15{ }^{\circ} \mathrm{C}$. Machado, MG, 2013.

variation among different photoperiod conditions, which allows the joint analysis of the data (Figure 2). Similarly, the variation in matter accumulation was negligible, and overall adjustment of the data can be observed with a high coefficient of determination that is higher than the adjustment obtained for the scale in days. Considering growing degree days calculated with $\mathrm{Tb}=12{ }^{\circ} \mathrm{C}$, the phenology of the purple nutsedge can be predicted by $y=0.113 x$, while the species growth can be predicted by $y=37.678 /\left(1+(x / 509.353)^{-7.047}\right)$.

\section{ACKNOWLEDGMENT}

The authors would like to thank the Instituto Federal de Educação, Ciência e Tecnologia do Sul de Minas Gerais IFSULDEMINAS, specially campus Machado, for fostering the development of this work.

\section{LITERATURE CITED}

BENDIXEN, L. E.; NANDIHALLI, U. B. Worldwide distribution of purple and yellow nutsedge (Cyperus rotundus and C. esculentus). Weed Technol., v. 1, n. 1, p. 61-65, 1987.
BENINCASA, M. M. P. Análise de crescimento de plantas: noções básicas. Jaboticabal: FUNEP, 2004. 42 p.

BIANCO, S. et al. Estimativa da área foliar de plantas daninhas. XIII - Amaranthus retroflexus L. Ecossistema, v. 20, n. 1, p. 5-9, 1995.

CAO, W.; MOSS, D. N. Temperature and daylength interaction on phyllochron in wheat and barley. Crop Sci., v. 29, n. 4, p. 1046-1048, 1989.

CARVALHO, S. J. P.; CHRISTOFFOLETI, P. J. Estimativa da área foliar de cinco espécies do gênero Amaranthus usando dimensões lineares do limbo foliar. Planta Daninha, v. 25, n. 2, p. 317-324, 2007.

DURIGAN, J. C. Manejo da tiririca (Cyperus rotundus L.) antes e durante a implantação da cultura da cana-deaçúcar (Saccharum spp.). 1991. 336 f. Tese (Livre-Docência) - Universidade Estadual Paulista, Jaboticabal, 1991.

FOLONI, L. L. et al. Programa de manejo da tiririca (Cyperus rotundus) na cultura da cana-de-açúcar com aplicação isolada ou sequencial de MSMA. Planta Daninha, v. 26, n. 4, p. 883-892, 2008.

GADIOLI, J. L. et al. Temperatura do ar, rendimento de grãos de milho e caracterização fenológica associada à soma calórica. Sci. Agric., v. 57, n. 3, p. 377-383, 2000. 
GHERSA, C. M.; HOLT, J. S. Using phenology prediction in weed management: a review. Weed Res., v. 35, n. 6, p. 461-470, 1995.

GILMORE JR., E. C.; ROGERS, J. S. Heat units as a method of measuring maturity in corn. Agron. J., v. 50, n. 10, p. 611-615, 1958.

GRAMIG, G. G.; STOLTENBERG, D. E. Leaf appearance, base temperature and phyllochron for common grass and broadleaf weed species. Weed Technol., v. 21, n. 1, p. 249-254, 2007.

GRANIER, C.; TARDIEU, F. Is thermal time adequate for expressing the effects of temperature on sunflower leaf development? Plant Cell Environ., v. 21, n. 7, p. 695-703, 1998.

HESS, M. et al. Use of the extended BBCH scale - general for descriptions of the growth stages of mono-and dicotyledonous weed species. Weed Res., v. 37, n. 6, p. 433-441, 1997.

HOLM, L. G. et al. The world's worst weeds: distribution and biology. Honolulu: University Press Hawaii, 1977. 609 p.

HOLT, J. S.; ORKUTT, D. R. Functional relationships of growth and competitiveness in perennial weeds and cotton (Gossypium hirsutum). Weed Sci., v. 39, n. 4, p. 575-584, 1991.

KIRKBY, E. J. M. Factors affecting rate of leaf emergence in barley and wheat. Crop Sci., v. 35, n. 1, p. 11-19, 1995.

KISSMANN, K. G. Plantas infestantes e nocivas. 2. ed. São Paulo: BASF, 1997. v. 1. 825 p.

KUVA, M. A. et al. Fitossociologia de comunidades infestantes de plantas daninhas em agroecossistema canacrua. Planta Daninha, v. 25, n. 3, p. 501-511, 2007.
LORENZI, H. Manual de identificação e controle de plantas daninhas: plantio direto e convencional. 6. ed. Nova Odessa: Instituto Plantarum, 2006. 339 p.

LUCCHESI, A. A. Utilização prática de análise de crescimento vegetal. Anais ESALQ, v. 41, n. 1, p. 181-202, 1984.

MACHADO, E. C. R. et al. Initial growth and development of southern sandbur based on thermal units.

Planta Daninha, v. 32, n. 2, p. 335-343, 2014.

MEDEIROS, G. A. et al. Crescimento vegetativo e coeficiente de cultura do feijoeiro relacionados a graus-dia acumulados. Pesq. Agropec. Bras., v. 35, n. 9, p. 1733-1742, 2000.

RADOSEVICH, S.; HOLT, J. S.; GHERSA, C. Weed ecology: implications for vegetation management. New York: John Willey, 1997. 589 p.

RUSSELLE, M. P. et al. Growth analysis based on degree days. Crop Sci., v. 24, n. 1, p. 28-32, 1984.

SANDERSON, M. A.; WOLF, D. D. Morphological development of switchgrass in diverse environments. Agron. J., v. 87, n. 5, p. 908-914, 1995.

SILVA, A. P. P. et al. Growth and development of honey weed based on days or thermal units. Planta Daninha, v. 32, n. 1, p. 81-89, 2014.

STREIBIG, J. C. Herbicide bioassay. Weed Res., v. 28, n. 6, p. 479-484, 1988.

VILLA NOVA, N. A. et al. Modelo para previsão da produtividade do capim elefante em função da temperatura do ar, fotoperíodo e frequência de desfolha. R. Bras.

Agrometriol., v. 7, n. 1, p. 75-79, 1999. 